\title{
Disruption of the fibroblast growth factor-2 gene results in decreased bone mass and bone formation
}

\author{
Aldemar Montero, ${ }^{1}$ Yosuke Okada, ${ }^{1}$ Masato Tomita, ${ }^{1}$ Masako Ito, ${ }^{2}$ Hiroshi Tsurukami, ${ }^{3}$ \\ Toshitaka Nakamura, ${ }^{3}$ Thomas Doetschman, ${ }^{4}$ J. Douglas Coffin, ${ }^{5}$ and Marja M. Hurley ${ }^{1}$ \\ ${ }^{1}$ Department of Endocrinology and Metabolism, The University of Connecticut Health Center, Farmington, \\ Connecticut 06030, USA \\ ${ }^{2}$ Department of Radiology, Nagasaki University, Nagasaki, Japan \\ ${ }^{3}$ Department of Orthopoedic Surgery, University of Occupational and Environmental Health, Kitakyushu, Japan \\ ${ }^{4}$ Department of Molecular Genetics, University of Cincinnati, Cincinnati, Ohio 45267, USA \\ ${ }^{5}$ Department of Pharmaceutical Sciences, School of Pharmacy and Allied Health Sciences, University of Montana, \\ Missoula, Montana 59812, USA
}

Address correspondence to: Marja M. Hurley, Division of Endocrinology and Metabolism, The University of Connecticut Health Center, Farmington, Connecticut 06030-1850, USA. Phone: (860) 679-3483; Fax: (860) 679-1875; E-mail: hurley@nso1.uchc.edu.

Received for publication October 7, 1999, and accepted in revised form Feburary 24, 2000.

Basic fibroblast growth factor (FGF-2), an important modulator of cartilage and bone growth and differentiation, is expressed and regulated in osteoblastic cells. To investigate the role of FGF-2 in bone, we examined mice with a disruption of the Fgf2 gene. Measurement of trabecular bone architecture of the femoral metaphysis of $\mathrm{Fg} 2^{+/+}$and $\mathrm{Fg} \mathrm{f}^{-/-}$adult mice by micro-CT revealed that the platelike trabecular structures were markedly reduced and many of the connecting rods of trabecular bone were lost in the $\mathrm{Fgf2}^{-/-}$mice. Dynamic histomorphometry confirmed a significant decrease in trabecular bone volume, mineral apposition, and bone formation rates. In addition, there was a profound decreased mineralization of bone marrow stromal cultures from $\mathrm{Fgf2}^{-/-}$mice. This study provides strong evidence that FGF-2 helps determine bone mass as well as bone formation.

J. Clin. Invest. 105:1085-1093 (2000).

\section{Introduction}

Basic fibroblast growth factor (FGF-2) influences the proliferation and differentiation of a variety of cell types in vitro (1-5). It is stored in the extracellular matrix $(\mathrm{ECM})(3,6,7)$ and is expressed in osteoblasts (7). FGF2 has been shown to be an important modulator of cartilage and bone cell function $(2,8-10)$. Previously, we reported that overexpression of FGF-2 in transgenic mice resulted in achondroplasia and shortening of the long bones (11). Fibroblast growth factor receptors (FGFRs) are also important regulators of bone growth and development and are differentially expressed in bone and cartilage $(2,12,13)$. A number of human dysmorphic syndromes have been genetically linked to mutations in different FGFRs $(2,14,15)$. Disruption of the FGFR3 gene in mice resulted in increased endochondral bone growth $(16,17)$, whereas mutations in FGFR2 increased expression of osteoblast differentiation markers in calvarial osteoblasts (18). FGFR2 is essential for limb bud initiation, and loss of FGFR1 results in distal truncation of mouse limb bud (19).

In bone cell cultures, FGF-2 stimulated replication (20) and reduced differentiation markers such as alkaline phosphatase and type 1 collagen (21-24). In contrast to continuous treatment, intermittent FGF-2 treatment stimulated bone formation in vitro (23) and in vivo $(2,25)$. In vivo studies in rats have consistently shown that FGF-2 stimulated new bone formation on endosteal and trabecular bone surfaces but not on periosteal surfaces (25-27). Several groups have reported on the anabolic effect of FGF-2 to restore bone mass in ovariectomized (OVX) rats (28-30), a well-established model for postmenopausal bone loss. FGF-2 not only stimulated bone formation on preexisting bone surfaces, but also induced de novo formation of bone spicules within the marrow cavity, resulting in partial restoration of the loss of cancellous bone mass in the osteopenic OVX rats (30). That FGF-2 treatment increased cancellous bone in the marrow cavity $(25,30)$ suggests that osteoblast precursors in the marrow cavity are a target cells for the effects of FGF-2. This observation is important, as bone marrow contains osteoblast precursors/stromal cells that synthesize FGF2 (31) and responds to FGF-2 in an autocrine/paracrine manner (32-35). FGFs also play an important role in fracture repair in rats (36) and in humans (37). The Fgf2 gene is expressed at an early stage of fracture repair in granulation tissue at the fracture site (38). FGF-2 is also a potent stimulator of osteoclast formation and bone resorption $(5,39,40)$. Thus, FGF-2 should be considered as an important regulator of osteoclastic-osteoblastic interaction or coupling.

FGF-2 is expressed in osteoblasts $(20,41-43)$, osteocytes, and periosteal cells (42). Fgf2 mRNA and protein levels are increased in osteoblasts by transforming growth factor $\beta$ (41), prostaglandins (42), and parathy- 
roid hormone (43). Thus, hormones and local factors, which have important functions in bone homeostasis, regulate FGF-2 production.

These data demonstrate that FGF signaling plays important roles in bone development. Because there are at least 17 FGFs besides FGF-2, many of which have multiple receptor specificities (44-50), it is important to determine which ligands play specific roles in skeletogenesis. Recently, $\mathrm{Fg} f 2^{-/}$mice were developed in a Black Swiss $\times 129$ Sv genetic background (51). These mice are viable and reproduce. $\mathrm{Fg} f 2^{-/}$mice have decreased vascular smooth muscle contractility, low blood pressure, and thrombocytosis. They also have a diminished response to IL-3. a cytokine that stimulates hematopoietic multilineage proliferation and differentiation (52). Fgf2 $2^{-/-}$mice were shown to have delayed wound healing (53) and neuronal defects and impaired development of the cerebral cortex $(53,54)$.

Because FGF-2 has profound effects on osteoblast replication and differentiation, we examined the effect that deletion of the Fgf2 gene had on bone formation. This study provides strong evidence that FGF-2 is an important determinant of bone mass and is a regulator of bone formation.

\section{Methods}

Mice were bred and housed in the transgenic facility in the center for laboratory animal care at the University of Connecticut Health Center. Mice were sacrificed by $\mathrm{CO}_{2}$ narcosis and cervical dislocation. Animal protocols were approved by the Animal Care Committee of the University of Connecticut Health Center.

Cell replication. Osteoblastic cells populations of 2-5 cells that are a mixture of preosteoblasts, osteoblasts, and osteocytes were prepared from the calvariae of 8week-old $\mathrm{Fg} \mathrm{C}^{+/+}$and $\mathrm{Fg} / 2^{-/-}$mice by sequential digestion with $0.1 \%$ collagenase (Boehringer Mannhiem Biochemicals Inc., Indianapolis, Indiana, USA) and plated in $100-\mathrm{mm}$ dishes in DMEM with $10 \%$ heat inactivated FCS (Hyclone Laboratories, Logan, Utah, USA) for 12 days in a $5 \% \mathrm{CO}_{2}$ incubator at $37^{\circ} \mathrm{C}$. Cells were replated at a density of 5,000 cells $/ \mathrm{cm}^{2}$ for 7 days with media change every 3 days. For labeling studies, $\left[{ }^{3} \mathrm{H}\right]$ thymidine $(10 \mu \mathrm{Ci} /$ well $)$ was added for the last 4 hours of the culture to measure cell proliferation (20).

Bone marrow stromal cultures. Cells were isolated as described previously (55). Briefly, tibiae and femur from 6-month-old $\mathrm{Fg} 2^{+/+}$and $\mathrm{Fgf2} 2^{-/-}$mice were dissected free of adhering tissue. The ends were removed, and the marrow cavity was flushed with $\alpha$-MEM (GIBCO-BRL, Grand Island, New York, USA). Cells were plated at $2 \times 10^{6}$ cells/well, unless stated otherwise, in 6-multiwell plates in $\alpha$ MEM containing 10\% FCS; cultures were fed every 3 days with fresh differentiation media ( $\alpha$ MEM, $10 \mathrm{nM}$ dexamethasone, $10 \%$ FCS, $8 \mathrm{mM} \beta$-glycerophosphate, $50 \mu \mathrm{g} / \mathrm{mL}$ ascorbic acid). Cells were fixed and stained for alkaline phosphatase using a commercially available kit (Sigma Chemical Co., St. Louis, Missouri, USA). Colony num- ber and area was determined by NIH Image (version 1.61; National Institutes of Health, Bethesda, Maryland, USA). Some dishes were then restained with von Kossa reagent to determine mineralization.

Measurement of $m R N A$ levels. Osteoblastic cells were prepared from calvariae of 8-week-old $\mathrm{Fg} / 2^{+/+}$and $\mathrm{Fg} \mathrm{2}^{-/-}$ mice as already described here. Second-passage cells were plated at 5,000 cells $/ \mathrm{cm}^{2}$ in DMEM with FCS (10\%); ascorbic acid $(50 \mu \mathrm{g} / \mathrm{mL})$, and $\beta$-glycerophosphate $(8$ $\mathrm{mM}$ ) for 7-21 days. Total RNA was extracted from cells by the method of Chomczynski and Sacchi (56). For Northern analysis, $20 \mu \mathrm{g}$ of total RNA was denatured and fractionated on a $0.8 \%$ agarose $/ 1.1 \mathrm{M}$ formaldehyde gel, transferred to filters by capillary blotting or positive pressure, and fixed to the filter by ultraviolet irradiation (Stratalinker; Stratagene, La Jolla, California, USA) (57). After a 4-hour prehybridization, filters were hybridized overnight with a $\left[{ }^{32} \mathrm{P}\right]$-labeled mouse cDNA probe for either Fgf1 or Fgf2 (58).

Bone histomorphometry. $\mathrm{Fg} 2^{-/-}$mice appeared normal and had no significant size or weight differences compared with $\mathrm{Fgf2} 2^{+/+}$mice. $\mathrm{Fg} \mathrm{f}^{+/+}$and $\mathrm{Fg} \mathrm{f}^{-/-}$mice at 4.5 months or 8 months of age were weighed and injected on day 1 with calcein at $0.6 \mathrm{mg} / 100 \mathrm{~g}$ body weight; a second injection was administered on day 5 ; and mice were sacrificed on day 8 . The right proximal tibiae were fixed with $10 \%$ buffered formalin followed by $100 \%$ ethanol, then embedded in methyl methacrylate (MMA), Five-micrometer-thick midfrontal sections of the proximal tibiae were obtained using a Reichert microtome (Reichert-Jung, Heidelburg, Germany). The left proximal tibiae were fixed with $4 \%$ paraformaldehyde and embedded in a mixture of MMA, hydroxyglyucol methacrylate, and 2-hydroxyethylacrylate. Polymerization was performed at $4^{\circ} \mathrm{C}$. Then, undecalcified $5-\mu \mathrm{m}$ sections were stained for tartrate-resistant acid phosphatase (TRAP) (59).

Histomorphometry was performed with a semiautomatic image-analyzing system linked to a light microscope (Cosmozone 1S; Nikon, Tokyo, Japan). The area of the secondary spongiosa was analyzed excluding the region within $0.5 \mathrm{~mm}$ of the growth plate-metaphyseal junction (60). The tibial metaphyseal cancellous bone area $4.5 \mathrm{~mm}$ distal to the growth plate-metaphyseal junction was analyzed. Trabecular bone volume density (BV/TV, \%), was measured, and the trabecular thickness (Tb.Th, $\mu \mathrm{m}$ ) and trabecular number (Tb.N, $\mathrm{mm}^{-1}$ ) were calculated by the parallel plate method of Parfitt et al. (61). The Tb.N was defined as the number of intersections between bone and nonbone components per total length of test lines applied to a specimen (62). Osteoclast surface (Oc.S/BS, \%) and osteoclast number (Oc.N/BS, $\mathrm{mm}$ ) were determined. Oc.N/BS, mm were TRAP-positive cells that formed resorption lacunae at the surface of the trabeculae and contained more than 1 nuclei that were identified as osteoclasts. For dynamic histomorphometry, mineralizing surface (DLS/BS, \%), mineral apposition rate (MAR, $\mu \mathrm{m} / \mathrm{d}$ ), and bone formation rate (BFR/BS, $\mu \mathrm{m}^{3} / \mu \mathrm{m}^{2}$ per day) were also measured. 


\section{Figure 1}

Northern analysis for Fgf2 mRNA expression in primary calvarial osteoblasts prepared from 7-day-old $\mathrm{Fg}_{\mathrm{g} 2^{+/+}}$and $\mathrm{Fg} \mathrm{f}^{-/-}$mice. Total RNA was extracted from cells after 7, 9, 14, and 21 days of culture. A 6-kb Fof2 mRNA transcript was expressed in calvarial osteoblast cultures from $\mathrm{Fg} 2^{+/+}$mice (lanes 1, 3, 5, and 7). No Fof2 mRNA transcript was detected in osteoblasts from $\mathrm{Fgf2}^{-/-}$mice (lanes 2, 4, 6, and 8).

Micro-CT scanning of trabecular bone of the distal metaphysis of the femur of $\mathrm{Fg} / 2^{+/+}$and $\mathrm{Fg} \mathrm{2}^{-/-}$mice. The femoral cancellous bones of the distal metaphysis were analyzed by the micro-CT system ( $\mu$ CT-20; Scanco Medical, Zurich, Switzerland), as reported previously (63). Using 2-dimensional data from scanned slices, 3-dimensional analysis was performed to calculate morphometric indices including bone volume density (bone volume $[\mathrm{BV}] /$ tissue volume $[\mathrm{TV}])$, trabecular thickness (Tb.Th $=2 \times \mathrm{BV} /$ bone surface $[\mathrm{BS}])$, trabecular number $[\mathrm{Tb} . \mathrm{N}=(\mathrm{BV} / \mathrm{TV}) / \mathrm{Tb} . \mathrm{Th}]$, and trabecular separation $[\mathrm{Tb} . \mathrm{Sp}=(1 / \mathrm{Tb} . \mathrm{N})-\mathrm{Tb} . \mathrm{Th}]$. These parameters were calculated by the parallel plate model of Parfitt et al. (61). The Tb.N was defined as the number of intersections between bone and nonbone components per total length of test lines applied to a specimen (62).

Statistical analysis. Statistical significance among means was assessed by ANOVA and the Tukey-Kramer multiple comparison test when ANOVA demonstrated significant differences among means.

\section{Results}

FGF mRNA expression in calvarial osteoblasts from $\mathrm{Fg} 2^{+/+}$ and $\mathrm{Fg}_{2} 2^{-1-}$. To confirm disruption of the Fgf2 gene, total RNA was extracted from calvarial osteoblastic cells from both genotypes. The upper panel in Figure 1 (lanes 1, 3, 5, and 7) shows the expression of a 6-kb Fgf2 mRNA transcript in osteoblastic cells from $\mathrm{Fg} f 2^{+/+}$mice. There was no detectable Fgf2 mRNA transcript in the osteoblasts from $\mathrm{Fg} 2^{-/-}$mice (Figure 1, lanes 2, 4, 6, and $8)$. Because acidic FGF (FGF-1) has similar effects as FGF-2 on bone (2) and is stored in the bone matrix (3), we determined whether it was expressed in osteoblasts from $\mathrm{Fgf2}^{--}$mice. Northern analysis showed no Fgf1 mRNA transcript in osteoblasts of either genotype. However, Fgf1 mRNA was expressed in brain tissue from $\mathrm{Fg} 2^{+/+}$mice, which was used as a positive control (data not shown).

Effect of disruption of the Fgf2 gene on bone cell replication. We measured thymidine incorporation into DNA in calvarial osteoblasts from 8-week-old $\mathrm{Fgf2}^{+/+}$and $\mathrm{Fg} \mathrm{f}^{-/-}$ mice. Thymidine incorporation into DNA was significantly reduced by $69 \%$ in calvarial osteoblast cultures from $\mathrm{Fgf2}^{-/-}$mice (Figure 2). We compared the ability of 24-hour treatment with exogenous FGF-2 to increase cell replication in these cultures. The addition of FGF-2 $(10 \mathrm{nM})$ increased cell replication in osteoblasts from both genotypes.

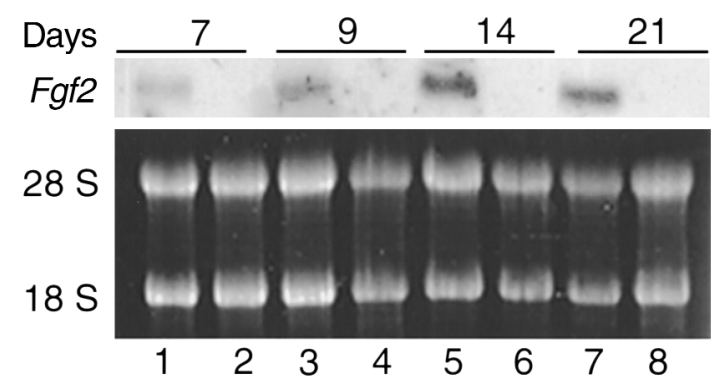

Alkaline phosphatase-positive colonies and mineralized nodules in bone marrow cultures of $\mathrm{Fg} 2^{+/+}$and $\mathrm{Fg} \mathrm{2}^{-/-}$mice. We assessed whether disruption of the $\mathrm{Fg} 2 \mathrm{~g}$ gene would alter the formation of alkaline phosphatase-positive (ALP) colonies and mineralized nodules in bone marrow cultures from $\mathrm{Fg} 2^{-1-}$ mice. Bone marrow cells were plated at a low density $1 \times 10^{6}$ cells per well in the absence and presence of FGF-2 (10 nM), which was added for the first 3 days of the 14-day culture period. The number of ALP colonies were counted and colony area was measured using NIH Image (version 1.61). Comparison of vehicle-treated bone marrow cultures from both genotypes showed fewer ALP colonies ( $29+4$ vs. $16+0.8 ; P<$ $0.05)$ and decreased colony area $(0.24+0.05$ vs. $0.07+$ $0.01 ; P<0.05)$ in bone marrow cultures from $\mathrm{Fg} \mathrm{f}^{-1-}$ mice. The effect of FGF- 2 treatment on colony area is shown in Figure 3a. There was a significant increase in colony area in response to FGF-2 treatment. However,

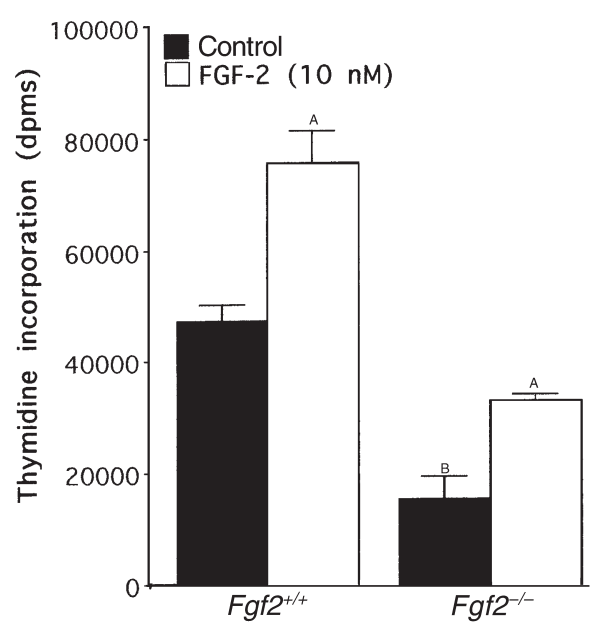

Figure 2

Comparison of thymidine incorporation into DNA in calvarial osteoblasts from 8-week-old $\mathrm{Fg} \mathrm{F}^{+/+}$and $\mathrm{Fgf2}^{-/-}$mice. Osteoblastic cells were prepared from calvariae of 8-week-old $\mathrm{Fgf2}^{+/+}$and $\mathrm{Fgf2}^{-/-}$ mice and plated in 100-mm dishes in DMEM with $10 \%$ heat inactivated FCS for 12 days. Cells were harvested and replated at a density of 5,000 cells $/ \mathrm{cm}^{2}$ for 7 days. Media were changed every 3 days. Cultures were treated with fresh media in the absence or presence of FGF-2 (10 nM) for the last 24 hours of the culture period. For labeling studies, $\left[{ }^{3} \mathrm{H}\right]$ thymidine $(10 \mu \mathrm{Ci} /$ well $)$ was added for the last 4 hours of the culture to measure thymidine incorporation into DNA. Values are the mean \pm SEM for 6 determinations per group. ASignificantly different from control cultures; $P<0.05$. BSignificantly different from $\mathrm{Fg}_{2}{ }^{+/+} ; P<0.05$. 
colony area remained reduced in the bone marrow cultures of $\mathrm{Fgf2}^{--}$mice compared with the response to FGF-2 treatment in bone marrow cultures from $\mathrm{Fg} / 2^{+/+}$ mice. In some experiments, bone marrow cells were plated at $20^{6}$ cells per well and cultured for 13 or 21 days, stained for ALP, and then restained for mineral by the

a

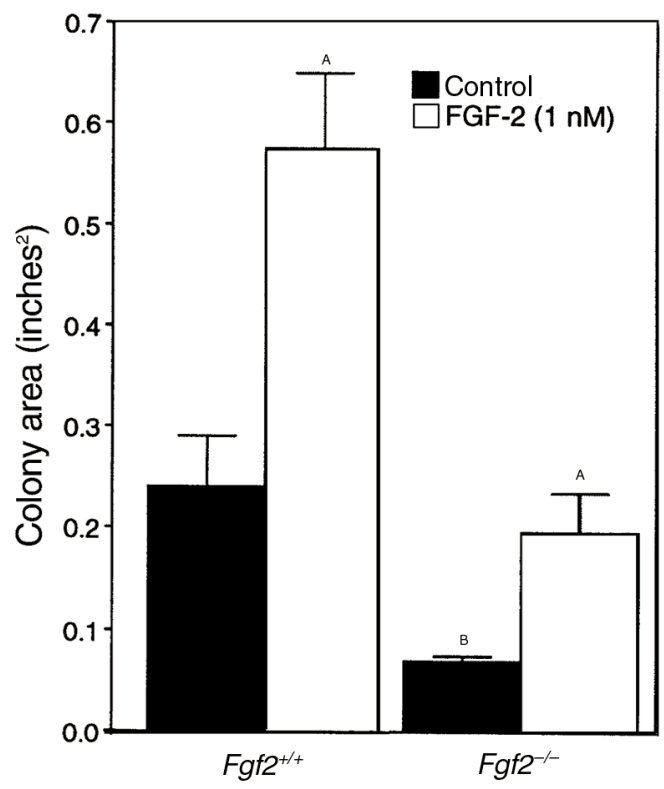

b
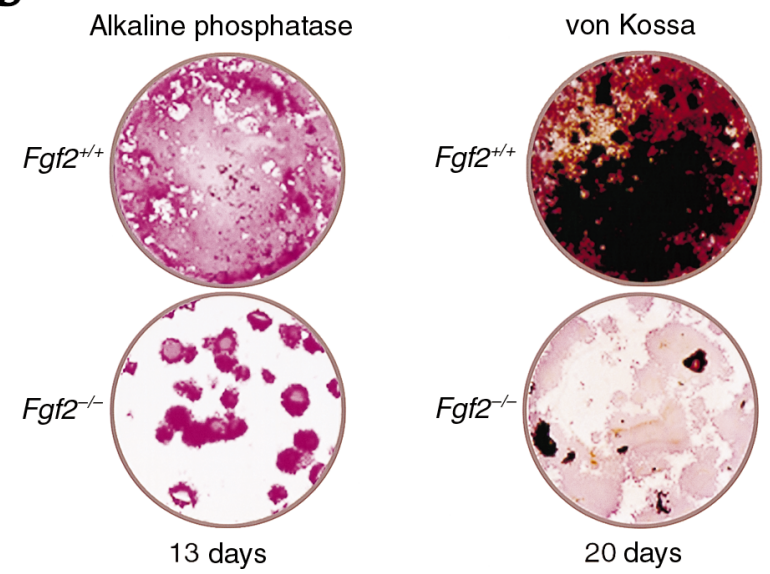

Figure 3

(a) Effect of FGF-2 on colony area in mouse bone marrow cultures from $\mathrm{Fg}_{2}{ }^{+/+}$and $\mathrm{Fg} \mathrm{2}^{-/-}$mice. Cells were plated at a density of 1 million cells per well in $\alpha$ MEM containing penicillin/streptomycin and $10 \%$ heat inactivated FCS in the absence or presence of FGF-2 (10 $\mathrm{nM})$. On day 3 , media were changed and cells were cultured in differentiation media ( $\alpha$ MEM, $10 \mathrm{nM}$ dexamethasone, 10\% FCS, $8 \mathrm{mM}$ $\beta$-glycerophosphate, $50 \mu \mathrm{g} / \mathrm{mL}$ ascorbic acid) for an additional 11 days. ASignificantly different from control cultures; $P<0.05$. ${ }^{B}$ Significantly different from $\mathrm{Fg}^{+/+} ; P<0.05$. (b) Comparison of the ability to form ALP colonies and mineralized nodules as determined by von Kossa staining in mouse bone marrow cultures from $\mathrm{Fg}^{+/++}$and Fof $2^{-1-}$ mice. Cells were plated at a density of 20 million cells per well in $\alpha M E M$ containing penicillin/streptomycin and $10 \%$ heat inactivated FCS. On day 3 , media were changed and cells were cultured in differentiation media ( $\alpha$ MEM, $10 \mathrm{nM}$ dexamethasone, 10\% FCS, $8 \mathrm{mM}$ $\beta$-glycerophosphate, $50 \mu \mathrm{g} / \mathrm{mL}$ ascorbic acid) for the indicated times. von Kossa method (Figure 3b). In these cultures, we were unable to count discrete ALP colonies in cultures from $\mathrm{Fg} 2^{+/+}$because of the diffuse staining; however, even at such high initial plating densities, discrete colonies were seen in bone marrow cultures of the $\mathrm{Fg} f 2^{-1-}$ mice. There were fewer ALP colonies after 13 days and minimal staining for mineral after 20 days in the bone marrow cultures of $\mathrm{Fg}^{-1-}$ mice compared with $\mathrm{Fg} 2^{+/+}$cultures (Figure $3 \mathrm{~b}$ ).

Micro-CT analysis of trabecular bone of the distal metaphysis of the femur of 4.5 -month adult $\mathrm{Fg} 2^{+/+}$and $\mathrm{Fg} \mathrm{f}^{---}$mice. We examined bone microarchitecture in adult mice of both genotypes by micro-CT (63). Threedimensional images of the femoral metaphysis of 4.5month-old male $\mathrm{Fgf2} 2^{+/+}$and $\mathrm{Fg} \mathrm{f}^{-/-}$mice are shown in (Figure 4). The platelike structure of the trabecular bone was markedly reduced, and the connecting rods of trabeculae were disrupted in $\mathrm{Fgf2}^{-/-}$mice compared with $\mathrm{Fg} 2^{+/+}$mice (Figure 4). Using 2-dimensional images, total area, bone area, and bone perimeter were determined from which the BV/TV, Tb.Th, Tb.N, and Tb.Sp were calculated. Figure 5 shows that the calculated 3dimensional parameters. BV/TV and Tb.N were significantly decreased by $34 \%$ and $31 \%$, respectively, and $\mathrm{Tb} . \mathrm{Sp}$ was significantly increased by $63 \%$ in $\mathrm{Fg} \mathrm{f}^{-/-}$mice compared with $\mathrm{Fg} \mathrm{f}^{+/+}$mice. Tb.Th was not different between the 2 genotypes at this age (data not shown).

Static and dynamic histomorphometric analysis of tibiae of 4.5-month $\mathrm{Fgf2}^{+/+}$and $\mathrm{Fgf2} 2^{-/-}$mice. Static histomorphometric analysis of the right proximal tibiae of 4.5month-old mice confirmed the micro-CT findings. Structural parameters of bone volume and trabecular number were significantly reduced and trabecular separation was significantly increased in $\mathrm{Fgf2}^{-/-}$mice compared with $\mathrm{Fgf}^{+/+}$mice (Table 1). As with micro-CT, trabecular thickness was unchanged (data not shown). Parameters of bone resorption were determined using the left proximal tibiae. Osteoclast surface and osteoclast number were reduced in $\mathrm{Fg} \mathrm{f}^{-/-}$bones, but the differences did not achieve statistical significance.

To determine whether the decrease in bone mass was due to a decrease in bone formation dynamic, histomorphometric parameters of bone formation were determined. Quantification of bone formation in the right proximal tibiae is shown in Table 2. Doublelabeled surface, mineral apposition rate, and bone formation rate were all significantly reduced in $\mathrm{Fg} \mathrm{f}^{-1}$ mice. These data are consistent with low turnover state in $\mathrm{Fgf2}^{-/-}$bones compared with $\mathrm{Fgf2} 2^{+/+}$bones and suggest that there is a marked defect in osteoblast proliferation and differentiation in $\mathrm{Fg} / 2^{-/-}$mice.

Histomorphometry of the distal femurs of 8-month-old $\mathrm{Fg} \mathrm{f}^{+/+}$and $\mathrm{Fg} \mathrm{f}^{-/-}$mice. We also examined undecalcified sections of the distal femurs of 8-month-old male $\mathrm{Fg} 2^{+/+}$(Figure 6a) and $\mathrm{Fg} 2^{-/-}$(Figure $6 \mathrm{~b}$ ) mice by darkfield illumination (60). The BV/TV and Tb.N in $\mathrm{Fg}^{-2^{-1-}}$ mice were reduced in the secondary spongiosa compared with $\mathrm{Fg} \mathrm{2}^{+/+}$mice. The trabecular separation was also increased in $\mathrm{Fg}^{-2^{-/}}$mice. 


\section{Figure 4}

Morphological study by micro-CT scanning of trabecular bone of the femurs of 4.5-month-old $\mathrm{Fg}^{+/ /+}$and Fof $2^{-1-}$ mice. Three-dimensional trabecular bone architecture of distal femoral metaphysis of 4.5-monthold male $\mathrm{Fg}_{2} 2^{+/+}$and $\mathrm{Fg} 2^{-/-}$mice were analyzed by micro-CT. Note that the platelike architecture of the trabecular bone is markedly reduced and the connecting rods of trabeculae are disrupted in Fgf2 ${ }^{-/-}$mice compared with $\mathrm{Fg} 2^{+/+}$
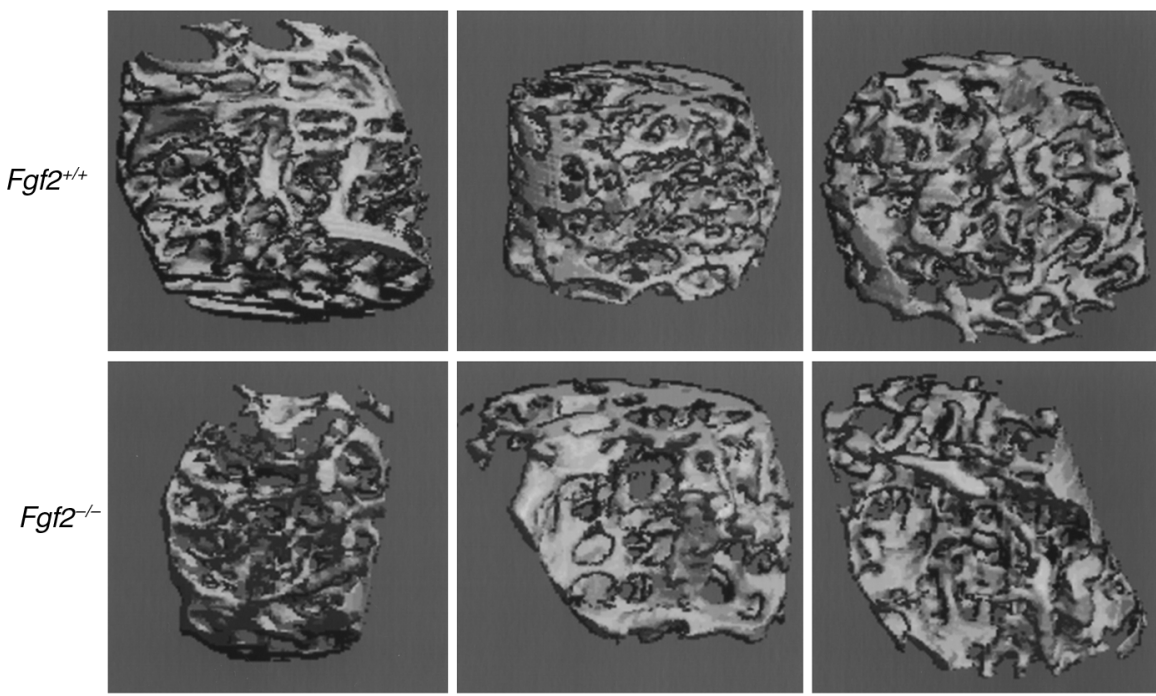

Micro-CT analysis of trabecular bone of the distal metaphysis of the femurs of 8-month-old $\mathrm{Fgf2} 2^{+/+}$and $\mathrm{Fgf2} 2^{-/-}$mice. We examined bone microarchitecture in 8-month-old mice of both genotypes by micro-CT. Table 3 shows that the calculated 3-dimensional parameters of $\mathrm{BV} / \mathrm{TV}$ and Tb.N were significantly decreased by $67 \%$ and $54 \%$, respectively, and $\mathrm{Tb} . \mathrm{Sp}$ was significantly increased by $249 \%$ in bones from the $\mathrm{Fg} \mathrm{2}^{-/-}$mice compared with $\mathrm{Fg} \mathrm{f}^{+/+}$mice. In contrast to our observation in the 4.5month-old mice, $\mathrm{Tb}$. Th was decreased by $27 \%$ in bones from these older $\mathrm{Fgf2}^{-/-}$mice.

Static histomorphometric analysis of tibiae of 8-month-old $\mathrm{Fg} 2^{+/+}$and $\mathrm{Fg}^{2} 2^{-/-}$mice. We performed static histomorphometric analysis of the right proximal tibiae of 8month-old mice. As shown in Table 4, structural parameters of bone volume and trabecular number were significantly reduced and trabecular separation was significantly increased in $\mathrm{Fg}_{2} 2^{-/-}$mice compared with $\mathrm{Fof} 2^{+/+}$mice. These data confirm the micro-CT results obtained from the distal femora of 8-month-old Fgf2-/mice as shown in Table 3. Parameters of bone resorption were determined in the left proximal tibia. In these older mice, osteoclast surface was reduced by $48 \%$ in $\mathrm{Fg} f 2^{-/-}$, but osteoclast number was not significantly decreased.

\section{Discussion}

We hypothesized that disruption of the Fgf2 gene, might result in decreased bone formation, as FGF-2 is a potent

\section{Table 1}

Static histomorphometric parameters of bone structure at right proximal tibia in 4.5-month-old $F g 2^{+/+}$and $F g 2^{-/-}$mice

\begin{tabular}{|c|c|c|c|c|}
\hline Genotype & $n$ & $\begin{array}{c}\text { Bone } \\
\text { volume } \\
(\mathrm{BV} / \mathrm{TV} ; \%)\end{array}$ & $\begin{array}{c}\text { Trabecular } \\
\text { number } \\
\text { (Tb.N; mm-1) }\end{array}$ & $\begin{array}{c}\text { Trabecular } \\
\text { separation } \\
\text { (Tb.Sp; } \mu \mathrm{m})\end{array}$ \\
\hline$F g f 2^{+/+}$ & 3 & $16.1(2.2)$ & $4.95(0.7)$ & $173(32.2)$ \\
\hline Fgf $2^{-/-}$ & 3 & $9.4(2.0)^{\mathrm{A}, \mathrm{B}}$ & $2.95(1.0)^{A}$ & $334(117)^{A}$ \\
\hline
\end{tabular}

mitogen for osteoblasts and osteoblast precursors (20, 2 ) as well as a stimulator of bone formation $(2,25-30)$. Furthermore, FGF-2 is differentially expressed in the growth plate of long bones during the process of endochondral bone formation (64). Cross-sectional immunohistochemical studies of 18 day rat fetuses showed that FGF-2 staining was present in chondrocytes in the early stages of differentiation (64). The centers of ossification, calcified matrix, and osteoblasts also contained intense staining for FGF-2 (64). Other studies examined Fgf2 mRNA and protein by in situ hybridization and immunohistochemistry, respectively, and showed expression in resting and proliferative chondrocytes of the epiphyseal growth plate of human fetus (65). In earlier studies, bone marrow stromal cells were shown to synthesize and release FGF-2 (31) and to proliferate in response to FGF-2. These studies suggested a possible role for $\mathrm{Fg} 2 \mathrm{in}$ endochondral bone formation.

In this report, we show that proliferation was decreased in calvarial osteoblastic cells derived from 8week-old $\mathrm{Fgf2}^{-1-}$ mice. As shown in Figure 2, at the end of 7 days of culture, thymidine labeling was significantly reduced in the $\mathrm{Fg} 2^{-/-}$calvarial osteoblast cultures compared with $\mathrm{Fg} \mathrm{2}^{+/+}$calvarial osteoblast cultures. Thus, endogenous FGF-2 appears to be important in maintaining the basal rate of osteoblast replication. The addition of exogenous FGF-2 to the calvarial osteoblast cultures of both genotypes induced

Table 2

Dynamic histomorphometric parameters of bone formation at right proximal tibia in 4.5-month-old $\mathrm{Fg}^{2} 2^{+/+}$and $\mathrm{Fg}^{2} 2^{-/-}$mice

\begin{tabular}{|c|c|c|c|c|}
\hline Genotype & $n$ & $\begin{array}{l}\text { Double-labeled } \\
\text { surface } \\
\text { (D-LS/BS; \%) }\end{array}$ & $\begin{array}{c}\text { Mineral } \\
\text { apositional rate } \\
(\mathrm{MAR} ; \mu \mathrm{m} / \mathrm{d})\end{array}$ & $\begin{array}{c}\text { Bone } \\
\text { formation rate } \\
\left(\mathrm{BFR} / \mathrm{BS} ; \mu \mathrm{m}^{3} / \mu \mathrm{m}^{2} \text { per day }\right)\end{array}$ \\
\hline$F g 2^{+/+}$ & 3 & $7.50(1.68)$ & $1.69(0.10)$ & $22.9(5.37)$ \\
\hline Fgf $2^{-/-}$ & 3 & $4.53(1.25)^{\mathrm{A}}$ & $1.42(0.02)^{A}, B$ & $13.3(1.46)^{\mathrm{A}, \mathrm{B}}$ \\
\hline
\end{tabular}


Table 3

The 3-dimensional parameters of micro-CT of femora from 8-monthold $\mathrm{Fg}_{2}{ }^{+/+}$and $\mathrm{Fg} 2^{-/-}$mice

\begin{tabular}{|c|c|c|c|c|c|}
\hline Genotype & $n$ & $\begin{array}{c}\text { Bone } \\
\text { volume } \\
\text { (BV/TV; \%) }\end{array}$ & $\begin{array}{c}\text { Trabecular } \\
\text { number } \\
\left(\text { Tb.N; } \text { mm }^{-1}\right)\end{array}$ & $\begin{array}{l}\text { Trabecular } \\
\text { thickness } \\
\text { (Tb.Th } \mu \mathrm{m})\end{array}$ & $\begin{array}{l}\text { Trabecular } \\
\text { separation } \\
\text { (Tb.Sp; } \mu \mathrm{m})\end{array}$ \\
\hline$F g f 2^{+/+}$ & 3 & $22.0(4.8)$ & $3.9(0.3)$ & $57.0(11.1)$ & 22) \\
\hline Fgf $2^{-1-}$ & 3 & $7.4(2.4)^{A, B}$ & $1.8(0.7)^{A, B}$ & 41. 7A,B (3.2) & $564^{\mathrm{A}, \mathrm{B}}(190)$ \\
\hline
\end{tabular}

${ }^{A} P<0.05$, significantly different from $F g f^{4 /+}$ group, Mann-Whitney $U$ test. ${ }^{B} P<$ 0.05 , significantly different from $\mathrm{Fg}^{+/+}$group, Tukey-Kramer multiple comparison test (ANOVA).

a mitogenic response. However, administration of recombinant FGF-2 (the $18-\mathrm{kDa}$ isoform) did not completely restore the proliferative response in calvarial osteoblast cultures from the $\mathrm{Fg} \mathrm{f}^{-/-}$mice.

We also found that bone marrow stromal cells from $\mathrm{Fg}^{2} \mathrm{2}^{-/-}$mice formed fewer ALP mineralized colonies (Figure $3 \mathrm{~b}$ ). These results could be due to a decrease in osteoblast precursor number, secondary to decreased replication. We conducted experiments to determine whether short-term addition of exogenous FGF-2 to bone marrow cultures from $\mathrm{Fg} \mathrm{f}^{+/+}$and $\mathrm{Fg} \mathrm{2}^{-\mathrm{I}^{-}}$mice would increase the number of ALP colonies and colony area. The ALP colony formation defect in bone marrow cultures of the $\mathrm{Fg} \mathrm{f}^{-/-}$mice was only partially restored by recombinant $18-\mathrm{kDa}$ FGF-2 treatment (Figure 3a). These results are interesting, as several studies suggest that specific isoforms of FGF-2 may differentially modulate cell phenotype $(66,67)$.

In mouse bones, there are 3 isoforms of FGF- 2 protein with molecular weights (MWs) of 18,21 , and $22 \mathrm{kDa}$. We confirmed in our previous report that deletion of the FGF-2 gene abrogated all isoforms of FGF-2 protein (51). Studies have shown that cells expressing only the low molecular wt (LMW; $18 \mathrm{kDa}$ ) FGF-2 isoform were more migratory than cells expressing only the higher molecular wt (HMW) forms $(66,67)$. Previous studies have demonstrated that the $18-\mathrm{kDa}$ FGF-2 is primarily localized to the cytoplasm, whereas the HMW proteins are localized to the nucleus and may be important in mediating the mitogenic response (66). In an earlier study, we examined the growth of smooth muscle cells from transgenic mice overexpressing LMW, HMW, or all MW isoforms of FGF-2 (67). We demonstrated that serum-stimulated growth was highest in cultured smooth cells expressing the HMW hFGF-2 isoforms, intermediate in cells with the non-nuclear LMW isoform, and lowest in wild-type cells. Furthermore, neutralizing anti-FGF-2 antibody markedly decreased

\section{Figure 5}

Three-dimensional microstructural parameters calculated using 2dimensional data obtained from micro-CT of femoral bones from 4.5month-old $\mathrm{Fg}_{2} 2^{++}$and $\mathrm{Fg}_{2} 2^{-/-}$mice. Calculated morphometric indices included bone volume density (bone volume [BV]/trabecular volume [TV]), trabecular number [Tb.N = (BV/TV)/Tb.Th], and trabecular sep-

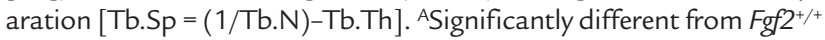
group; $P<0.05$, Tukey-Kramer multiple comparison test (ANOVA). serum stimulated DNA synthesis, but only in the cell lines overexpressing the exported/non-nuclear LMW isoform (67). These studies suggest an important role for the nuclear forms of FGF-2 in the mitogenic response to this growth factor. Therefore, it is possibly that in the absence of the HMW isoforms, treatment with LMW FGF-2 cannot completely rescue the proliferation defect that we observed in the calvarial osteoblast cultures or the ALP colony formation defect in bone marrow stromal cell cultures from $\mathrm{Fg} 2^{-/-}$mice. Currently, the HMW proteins are not available to determine whether addition of these proteins would fully restore these responses.

Bone marrow stroma is a complex tissue that contains pluripotent cells capable of differentiating into a variety of mesenchymal cell types $(68,69)$ including osteoblasts, which can differentiate and express alkaline phosphatase, type I collagen, and osteocalcin and produce a mineralizable matrix (69-71). Rat bone marrow stromal culture models have been used to demonstrate in vivo, the stimulatory effect of FGF-2 on bone formation (72-74). In vitro studies, using human bone marrow stromal cells, have shown that FGF-2 modulates the growth and expression of the osteogenic phenotype of human bone marrow-derived bonelike cells (75-78). As shown in a representative experiment in Figure 3b, there were fewer ALP, mineralized colonies formed in the bone marrow cultures from the $F g 2^{-/-}$mice. It is possible that in the absence of FGF-2, a factor(s) that promotes osteoblast differentiation is reduced or absent. Studies have shown that FGF-2 can synergize with plateletderived growth factor to maintain the osteogenic potential of rat marrow-derived mesenchymal cells (79). In addition, the combination of FGF-2 and bone morphogenic protein-2 was more potent than either factor alone in inducing new bone formation in rats (80).

Osteoblasts and adipocytes develop from multipotent mesenchymal stem cells of the bone marrow (81), and previous studies have shown that defective osteoblastogenesis and osteopenia in mice can be associated with increased adipogenesis and myelopoeisis (82). Because FGF-2 promotes development of other bone marrow lineage by affecting stromal cells and early committed hematopoetic progenitors (83), we examined the effect of disruption of the Fgf2 gene on hematopoetic bone marrow lineage in our previous publication (51). Methylcellulose culture of bone marrow cells revealed a decrease in hematopoetic colony formation in the $\mathrm{Fg} 2^{-/-}$mice, and increased number of megakaryocytes. Studies to examine adipogenesis in bone marrow cultures of the $F g f 2^{-/-}$mice are planned.
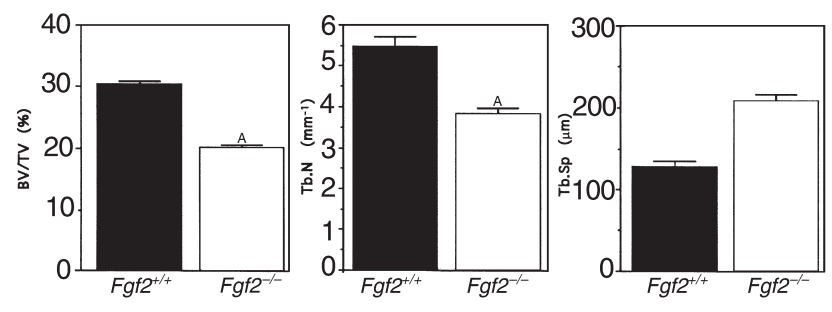
The micro-CT data (Figures 4 and 5) and the static and dynamic histomorphometric studies in the 4.5month-old $\mathrm{Fg}_{2} 2^{-/-}$mice (Tables 1 and 2) demonstrated a marked decrease in bone mass and a decreased rate of new bone formation that were quite consistent with each other. Increased trabecular separation was also found in the femora of 4.5 -month-old $\mathrm{Fg}^{2 / /-}$ mice. Dark-field examination of undecalcified distal femoral bones of older, 8-month-old $\mathrm{Fgf2} 2^{++}$(Figure 6a) and $\mathrm{Fgf2} 2^{-1-}$ (Figure 6b) mice show fewer trabeculae and loss of connectivity in the bones of $\mathrm{Fg} \mathrm{2}^{-/-}$mice compared with $\mathrm{Fg}_{2} 2^{+/+}$mice. The micro-CT data (Table 3) and the static histomorphometric data (Table 4) from these 8month-old mice demonstrate a more marked increase in trabecular separation, a further reduction in BV/TV and Tb.N and a decrease in Tb.Th. These data confirm the results observed in the 4.5 -month-old $\mathrm{Fg} \mathrm{F}^{-/-}$mice and further suggest that these changes are progressive as these mice age.

A decrease in the amount of bone and the number of trabeculae in the primary spongiosa could occur in $\mathrm{Fg} \mathrm{f}^{-/-}$bones if cartilage maturation was delayed that resulted in low peak bone mass. However, the growth plates of these mice showed no gross abnormality (51). We cannot rule out from the present studies the possibility that trabecular bone resorption was increased in $\mathrm{Fg} 2^{-/-}$mice in the very early stage of trabecular bone development and declined rapidly as the animal grew. However, an alternate explanation for these results is that because bone mass and structure are determined by the balance of bone formed and resorbed during turnover, there could be a negative balance if the bone resorption rate is not altered but is still greater than the rate of bone formation.

Dynamic histomorphometry (Table 2) confirms that there is a significant decrease in DLS/BS, BFR/BS, and MAR in the bones of 4.5-month-old Fof $2^{-1-}$ mice. These results are further supported by the in vitro bone formation data (Figure 3, a and b) that demonstrate a marked decrease in ALP colonies, colony area, and min-

\section{Table 4}

Static histomorphometric parameters of bone structure at right proximal tibia in 8-month-old $\mathrm{Fgf2}^{+/+}$and $\mathrm{Fg}^{-2^{-/}}$mice

\begin{tabular}{lcccc}
\hline Genotype & $n$ & $\begin{array}{c}\text { Bone } \\
\text { volume } \\
(\mathrm{BV} / \mathrm{TV} ; \%)\end{array}$ & $\begin{array}{c}\text { Trabecular } \\
\text { number } \\
\left(\mathrm{Tb} . \mathrm{N} ; \mathrm{mm}^{-1}\right)\end{array}$ & $\begin{array}{c}\text { Trabecular } \\
\text { separation } \\
(\mathrm{Tb} . \mathrm{Sp} ; \mu \mathrm{m})\end{array}$ \\
$\mathrm{Fg} \mathrm{2}^{+/+}$ & 3 & $18.1(4.8)$ & $4.7(0.7)$ & $177(31)$ \\
Fgf2 $^{-/-}$ & 3 & $7.9(2.4)^{\mathrm{A}, \mathrm{B}}$ & $2.7(1.0)^{\mathrm{A}}$ & $355(117)^{\mathrm{A}}$ \\
\hline
\end{tabular}

AP $<0.05$, significantly different from $\mathrm{Fg}^{\mathrm{f} /+}$ group, Mann-Whitney $U$ test. B $P<0.05$, significantly different from $\mathrm{Fgf}^{1 /+}$ group, Tukey-Kramer multiple comparison test (ANOVA).

eralized nodule formation in bone marrow stromal cultures from $\mathrm{Fg} f 2^{-/-}$mice compared with $\mathrm{Fg} \mathrm{f2}^{+/+}$. The decreased MAR is paradoxical, as several studies have shown that chronic FGF-2 treatment of osteoblastic cultures inhibited collagen synthesis, alkaline phosphatase activity, and osteocalcin synthesis (2). However, FGF-2 stimulates the proliferation of osteoblasts, and a number of in vitro and in vivo studies have shown that intermittent treatment with FGF-2 increases new bone formation $(2,25-30)$. This increase in new bone formation is only observed on the endosteal and trabecular bone surfaces. There is also increased newly formed cancellous bone filling the marrow spaces, suggesting that the target cells for this effect of FGF-2 are the osteoblast precursors present in the bone marrow. Thus, FGF-2 appears to inhibit the function of differentiated osteoblasts, whereas its anabolic action is probably due to an increase in the number of preosteoblasts that can then differentiate into mature osteoblasts capable of inducing new bone formation. Therefore, in the $\mathrm{Fg} \mathrm{f}^{-1-}$ mice, with fewer osteoblast precursors, the mature osteoblast population would also be reduced and hence MAR may be decreased by this mechanism.

In summary, our studies show that disruption of the $\mathrm{Fg} 2$ gene in mice results in decreased osteoblast replication, decreased mineralized nodule formation in bone marrow cultures, and decreased new bone formation in vivo. These data are the first to demonstrate an
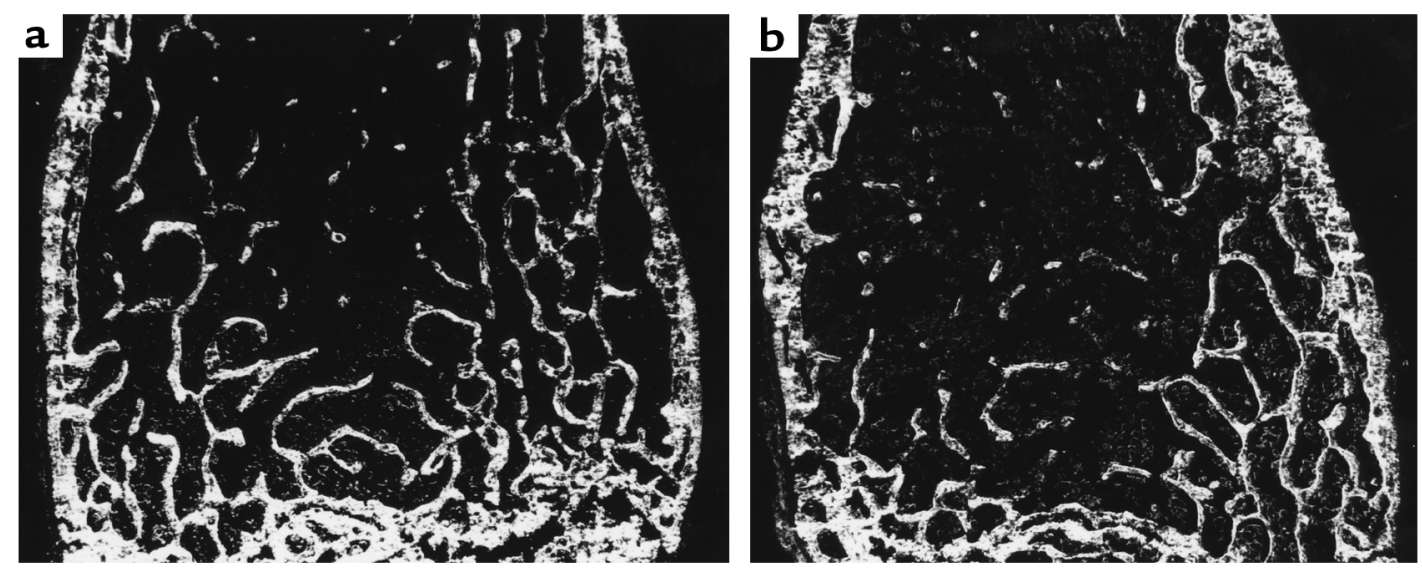

Figure 6

Undecalcified sections of the distal femur of (a) an 8-month-old $F g f 2^{+/+}$mouse and (b) a Fgf ${ }^{/-}$mouse (dark-field illumination). Trabecular number is decreased in the secondary spongiosa of the $\mathrm{Fgf2}^{-/-}$mouse. 
important role for endogenous FGF-2 in maintaining bone mass, as well as bone formation. We believe that the observations in the bones of the 4.5-month-old $\mathrm{Fgf2} 2^{-/}$mice are significant and are more marked in the older 8-month-old animals. These data further suggest that redundancy of members of the FGF family cannot compensate to prevent bone loss when the Fgf2 gene is disrupted in mice.

\section{Acknowledgements}

The authors wish to thank Lawrence Raisz (University of Conneticut School of Medicine, Farmington, Connecticut) for helpful discussion. This work was supported in part by NIH grants AR-46025 (to M.M. Hurley) and HL-53631 (to J.D. Coffin). The authors would also like to thank Jan Figueroa for clerical assistance.

1. Gospodarowicz, D. 1990. Basic science and pathology fibroblast growth factor chemical structure and biologic function. Clin. Orthop. Rel. Res. 257:231-248.

2. Hurley, M.M., and Florkiewicz, R. 1996. Fibroblast growth factor and vascular endothelial fibroblast growth factor families. In Principles of bone biology. Bilezikian, J.P., Raisz, L.G., and Rodan, G.A., editors. Academic Press. San Diego, CA. 627-645.

3. Hauschka, P.V., Mavrakos, A.E., Iafrati, M.D., Doleman, S.E., and Klagsbrun, M. 1986. Growth factors in bone matrix. J. Biol. Chem. 261:12665-12674 .

4. Shing, Y., et al. 1984. Heparin affinity: duplication of a tumour derived capillary endothelial cell growth factor. Science. 223:1926-1928.

5. Hurley, M.M., Kessler, M., Gronowicz, G., and Raisz, L.G. 1992. The interaction of heparin and basic fibroblast growth factor on collagen synthesis in 21-day fetal rat calvariae. Endocrinology. 130:2675-2681.

6. Saksela, O., and Rifkin, D. 1990. Release of basic fibroblast growth factor-heparan sulfate complexes from endothelial cells by plasminogen activator-mediated proteolytic activity. J. Cell Biol. 110:767-775.

7. Globus, R.K., Plouet, J., and Gospodarowicz, D. 1989. Cultured bovine bone cells synthesize basic fibroblast growth factor and store it in their extracellular matrix. Endocrinology. 124:1539-1547.

8. Hurley, M.M., et al. 1995. Transcriptional regulation of the collagenase gene by basic fibroblast growth factor in osteoblastic MC3T3-E1 cells. Biochem. Biophys. Res. Commun. 214:331-339.

9. Okazaki, R., et al. 1992. Transcriptional activation of the c-fos and c-jun proto-oncogenes by serum growth factors in osteoblast-like MC3T3-E1 cells. J. Bone. Miner. Res. 7:1149-1155.

10. Hurley, M.M., Marcello, K., Abreu, C., and Kessler, M. 1996. Signal transduction by basic fibroblast growth factor in rat osteoblastic Pyla cells. J. Bone Miner. Res. 11:1256-1263.

11. Coffin, J.D., et al. 1995. Abnormal bone growth and selective translational regulation in basic fibroblast growth factor (FGF-2) transgenic mice. Mol. Biol. Cell. 6:1861-1873.

12. Partanen, J., et al. 1991. FGFR4, a novel acidic fibroblast growth factor receptor with a distinct expression pattern. EMBO J. 10:1347-1354.

13. Orr-Urtreger, A., Givol, D., Yayon, A., Yarden, Y., and Lonai, P. 1991. Developmental expression of two murine fibroblast growth factor receptors, FLG and BEK. Development. 113:1419-1439.

14. Russeau, F., et al. 1994. Mutations in the gene encoding fibroblast growth receptor 3 in achondroplasia. Nature. 371:252-254.

15. Shiang, R., et al. 1994. Mutations in the transmembrane domain of FGFR3 cause the most common genetic form of dwarfism, achondroplasia. Cell. 78:335-342.

16. Deng, C., Wynshaw-Boris, A., Zhou, F., Kuo, A., and Leder, P. 1996. Fibroblast growth factor receptor 3 is a negative regulator of bone growth. Cell. 84:911-921.

17. Colvin, J.S., Bohne, B.A., Harding, G.W., McEwen D.G., and Ornitz, D.M. 1996. Skeletal overgrowth and deafness in mice lacking fibroblast growth factor receptor 3. Nat. Genet. 12:390-397.

18. Lomri, A., et al. 1998. Increased calvaria cell differentiation and bone matrix formation induced by fibroblast growth receptor 2 mutations in Apert syndrome. J. Clin. Invest. 101:1310-1317.

19. Xu, X., Weinstein M., Li, C., and Deng, C.X. 1999. Fibroblast growth factor receptors (FGFRs) and their role in limb development. Cell Tissue Res. 296:33-43

20. Globus, R.K., Patterson-Buckendahl, P., and Gospodarowicz, D. 1988. Regulation of bovine bone cell proliferation by fibroblast growth factor and transforming growth factor $\beta$. Endocrinology. 123:98-105.
21. Rodan, S.B., Wesolowski, G., Yoon, K., and Rodan, G.A. 1989. Opposing effects of fibroblast growth factor and pertussis toxin on alkaline phosphatase, osteopontin, osteocalcin and type I collagen mRNA levels in ROS 17/2.8 Cells. J. Biol. Chem. 264:19934-19941.

22. McCarthy, T.L., Centrella, M., and Canalis, E. 1989. Effects of fibroblast growth factors on deoxyribonucleic acid and collagen synthesis in rat parietal bone cells. Endocrinology. 125:2118-2126.

23. Canalis, E., Centrella, M., and McCarthy, T. 1988. Effects of basic fibroblast growth factor on bone formation in vitro. J. Clin. Invest. 81:1572-1577.

24. Hurley, M.M., et al. 1993. Basic fibroblast growth factor inhibits type I collagen gene expression in osteoblastic MC3T3-E1 cells. J. Biol. Chem. 268:5588-5593.

25. Mayahara, H., et al. 1993. In vivo stimulation of endosteal bone formation by basic fibroblast growth factor in rats. Growth Factors. 9:73-80.

26. Nakamura, T., et al. 1995. Stimulation of endosteal bone formation by systemic injections of recombinant basic fibroblast growth factor in rats. Endocrinology. 136:1276-1284.

27. Nagai, H., Tsukuda, R., and Mayahara, H. 1995. Effects of basic fibroblast growth factor (bFGF) on bone formation in growing rats. Bone. 16:367-373.

28. Nakamura, K., et al. 1998. Stimulation of bone formation by intraosseous injection of basic fibroblast growth factor in ovariectomized rats. Int. Orthop. 22:49-54.

29. Dunstan, C.R., et al. 1999. Systemic administration of acidic fibroblast growth factor (FGF-1) prevents bone loss and increases new bone formation in ovariectomized rats. J. Bone Miner. Res. 14:953-959.

30. Liang, H., Pun, S., and Wronski, T.J. 1999. Bone anabolic effects of basic fibroblast growth factor in ovariectomized rats. Endocrinology. 140:5780-5788

31. Brunner, G., Gabrilove, J., Rifkin, D.B., and Wilson, E.L. 1991. Phospholipase $\mathrm{C}$ release of basic fibroblast growth factor from human bone marrow cultures as a biologically active complex with a phosphatidylinositol anchored heparan sulfate proteoglycan. J. Cell Biol. 114:1275-1283.

32. Oliver, L.J., Rifkin, D.B., Gabrilove, J., Hannocks, M.J., and Wilson, E.L. 1990. Long-term culture of human bone marrow stromal cells in the presence of basic fibroblast growth factor. Growth Factors. 3:231-236.

33. Thomson, B.M., et al. 1993. Preliminary characterization of porcine bone marrow stromal cells: skeletogenic potential, colony-forming activity, and response to dexamethasone, transforming growth factor $\beta$, and basic fibroblast factor. J. Bone Miner. Res. 10:1173-1183.

34. Locklin, R.M., Williamson, M.C., Beresford, J.N., Triffitt, J.T., and Owen, M.E. 1995. In vitro effects of growth factors and dexamethasone on rat marrow stromal cells. Clin. Orthop. Rel. Res. 313:27-35.

35. Long, M.W., Robinson, J.A., Ashcraft, E.A., and Mann, K.G. 1995. Regulation of human bone marrow-derived osteoprogenitor cells by osteogenic growth factors. J. Clin. Invest. 95:881-887.

36. Kawaguchi, H., et al. 1994. Stimulation of fracture repair by recombinant human basic fibroblast growth factor in normal and streptozotocin-diabetic rats. Endocrinology. 135:774-781.

37. Wildburger, R., et al. 1994. Basic fibroblast growth factor (bFGF) immunoreactivity as a possible link between head injury and impaired bone fracture healing. J. Bone Miner. Res. 27:183-193.

38. Scully, S.P., Joyce, M.E., Abidi, N., and Bolander, M.E. 1990. The use of polymerase chain reaction generated nucleotide sequences as probes for hybridization. Mol. Cell Probes. 4:485-495.

39. Hurley, M.M., Lee, S.K., Raisz, L.G., Bernicker, P., and Lorenzo, J.A. 1998. Basic fibroblast growth factor induces osteoclast formation in murine bone marrow cultures. Bone. 22:309-316.

40. Kawaguchi, H., et al. 1995. Transcription induction of prostaglandin $\mathrm{G} / \mathrm{H}$ synthase- 2 by basic fibroblast growth factor. J. Clin. Invest. 96:923-930.

41. Hurley, M.M., Abreu, C., Gronowicz, G., Kawaguchi, H., and Lorenzo, J. 1994. Expression and regulation of basic fibroblast growth factor mRNA levels in mouse osteoblastic MC3T3-E1 cells. J. Biol. Chem. 269:9392-9396.

42. Sabbieti, M.G., et al. 1999. Prostaglandins regulate the expression of fibroblast growth factor-2 in bone. Endocrinology. 140:434-444.

43. Hurley, M.M., et al. 1999. Parathyroid hormone regulates the expression of fibroblast growth factor- $2 \mathrm{mRNA}$ and fibroblast growth factor receptor mRNA in osteoblastic cells. J. Bone Miner. Res. 14:776-783.

44. Cohen, M.M. 1997. Transforming growth factor Bs and fibroblast growth factors and their receptors: role in sutural biology and craniosynostosis. J. Bone Miner. Res. 12:322-331.

45. Ornitz, D.M., et al. 1996. Receptor specificity of the fibroblast growth factor family. J. Biol. Chem. 271:15292-15297.

46. Buckland, R.A., Collinson, J.M., Graham, E., Davison, D.R., and Hill, R.E. 1998. Antagonistic effects of FGF-4 on BMP induction of apoptosis and chondrogenesis in the chick limb bud. Mech. Dev. 71:143-150.

47. Kim, H.J., Rice, D.P., Kettunen, P.J., and Thesleff, I. 1998. FGF-, BMPand Shh-mediated signaling pathways in the regulation of cranial suture 
morphogenesis and calvarial bone development. Development. 125:1241-1251

48. Xu, J., Lawshe, A., MacArthur, C.A., and Ornitz, D.M. 1999. Genomic structure, mapping, activity and expression of fibroblast growth factor 17. Mech. Dev. 83:165-178.

49. Sekine, K., et al. 1999. FGF-10 is essential for limb and lung formation. Nat. Genet. 21:138-141.

50. Hartung, H., et al. 1997. Murine FGF-12 and FGF-13: expression in embryonic nervous system, connective tissue and heart. Mech. Dev. 64:31-39.

51. Zhou, M., et al. 1998. Fibroblast growth factor 2 control of vascular tone. Nat. Med. 4:201-207.

52. Hattersley, G. and Chambers, T.J. 1990. Effects of interleukin 3 and of granulocyte-macrophage and macrophage colony stimulating factors on osteoclast differentiation from mouse hematopoietic tissue. J. Cell Physiol. 142:201-209.

53. Ortega, S., Ittmann, M., Tsang, S.H., Erlich, M., and Bailico, C. 1998. Neuronal defects and delayed wound healing in mice lacking fibroblast growth factor 2. Proc. Natl. Acad. Sci. USA. 97:5672-5677.

54. Dono, R., Texido, G., Dussel, R., Ehmke, H., and Zeller, R. 1998. Impaired cerebral cortex development and blood pressure regulation in FGF-2deficient mice. EMBO J. 17:4213-4225.

55. Scutt, A., and Bertram, P. 1995. Bone marrow cells are targets for the anabolic actions of prostaglandin $\mathrm{E}_{2}$ on bone: Induction of a transition from nonadherent to adherent osteoblast precursors. J. Bone. Miner. Res. 10:474-487.

56. Chomczynski, P., and Sacchi, N. 1987. Single-step method of RNA isolation by acid guanidinium thiocyanate-phenol-chloroform extraction. Anal. Biochem. 162:156-159.

57. Towbin, H., Staehelin, T., and Gordon, J. 1979. Electrophoretic transfer of proteins from polyacrylamide gels to nitrocellulose sheets: Procedure and some applications. Proc. Natl. Acad. Sci. USA. 76:4350-4354.

58. Hebert, J.M., Basilico, C., Goldfarb, M., Haub, O., and Martin, G.R. 1990. Isolation of cDNAs encoding four mouse FGF family members and characterization of their expression patterns during embryogenesis. Dev. Biol. 138:454-463.

59. Narusawa, K., et al. 1995. The effect of recombinant human insulin-like growth factor (rhIGF)-1 and rhIGF-1/IGF binding protein- 3 administration on rat osteopenia induced by ovariectomy with concomitant bilateral sciatic neurectomy. J. Bone. Miner. Res. 10:1853-1864.

60. Murakami, H., Nakamura, T., Tsurukami, H., Abe, M., Barbier, A., and Suzuki, K. 1994. Effects of tiludronate on bone mass, structure, and turnover at the epiphyseal, primary, and secondary spongiosa in the proximal tibia of growing rats after sciatic neurectomy. J. Bone Miner. Res. 9:1355-1364.

61. Parfitt, A.M., et al. 1983. Relationships between surface, volume, and thickness of iliac trabecular bone in aging and osteoporosis. Implications for the microanatomic and cellular mechanisms of bone loss. J. Clin. Invest. 72:1396-1409.

62. Goulet, R.W., et al. 1994. The relationship between the structural and orthogonal compressive properties of trabecular bone. J. Biomech. 27:375-389.

63. Ruegsegger, P. and Muller, R. 1996. A microtomographic system for the nondestructive evaluation of bone architecture. Calcif. Tissue Int 58:61-75.

64. Gonzalez, A.-M., Buscaglia, M., Ong, M., and Baird A. 1990. Distribution of basic fibroblast growth factor in the 18-day rat fetus: localization in the basement membranes of diverse tissues. J. Cell Biol. 110:753-765.

65. Gonzalez, A.M., Hill, D.J., Logan, A., Maher, P.A., and Baird, A. 1996. Distribution of fibroblast growth factor (FGF)-2 and FGF receptor-1 mes- senger RNA expression and protein presence in the mid-trimester human fetus. Pediatr. Res. 39:375-385.

66. Bikfalvi, A., Klein, S., Pintucci, G., and Rifkin, D.B. 1997. Biological roles of fibroblast growth factor-2. Endocrine Rev. 18:26-45.

67. Davis, M.G., et al. 1997. Intracrine and autocrine effects of basic fibroblast growth factor in vascular smooth muscle cells. J. Mol. Cell Cardiol. 29:1061-1072.

68. Owen, M. 1985. Lineage of osteogenic cells and their relationship to the stromal system. W.A. Peck, editor. Bone and mineral research. 3:1-25.

69. Friedenstein, A.J. 1990. Osteogenic stem cells in the bone marrow. J. Bone Miner. Res. 7:243-272.

70. Stein, G.S., and Lian, J.B. 1993. Molecular mechanisms mediating proliferation/differentiation interrelationships during progressive development of the osteoblast phenotype. Endocr. Rev. 14:424-442.

71. Aubin, J.E., Liu, F., Malaval, L., and Gupta, A.K. 1995. Osteoblast and chondroblast differentiation. Bone. 17:77S-83S.

72. Lennon, D.P., Haynesworth, S.E., Young, R.G., Dennis, J.E., and Caplan, A.I. 1995. A chemically defined medium supports in vitro proliferation and maintains the osteochondral potential of rat marrow-derived mesenchymal stem cells. J. Exp. Cell Res. 219:211-222.

73. Noff, D., Pitaru, S., and Savion, N. 1989. Basic fibroblast growth factor enhances the capacity of bone marrow cells to form bone-like nodules In Vitro. FEBS Lett. 250:619-621.

74. Pitaru, S., Kotev-Emeth, S., Noff, D., Kaffuler, S., and Savion, N. 1993. Effect of basic fibroblast growth factor on the growth and differentiation of adult stromal bone marrow cells: enhanced development of mineralized bone-like tissue in culture. J. Bone Miner. Res. 8:919-926.

75. Wergedal, J.E., Mohan, S., Lundy, M., and Baylink, D.J. 1990. Skeletal growth factor and other growth factors known to be present in bone matrix stimulate proliferation and protein synthesis in human bone cells. J. Bone Miner. Res. 5:179-185.

76. Pri-Chen, S., Pitaru, S., Lokiec, F., and Savion, N. 1998. Basic fibroblast growth factor enhances the growth and expression of the osteogenic phenotype of dexamethasone-treated human bone marrow-derived bone-like cells in culture. Bone. 23:111-117.

77. Berrada, S., Lefebvre, F., and Harmand, M-F. 1995. The effect of recombinant human basic fibroblast growth factor RHFGF-2 on human osteoblasts in growth and phenotype expression. In Vitro Cell Dev. Biol Anim. 31:698-702.

78. Martin, I., Muraglia, A., Campanile, G., Cancedda, R., and Quarto, R. 1997. Fibroblast growth factor-2 supports ex vivo expansion and maintenance of osteogenic precursors from human bone marrow. Endocrinology. 138:4456-4462.

79. Scutt, A., and Bertram, P. 1999. Basic fibroblast growth factor in the presence of dexamethasone stimulates colony formation, expansion, and osteoblastic differentiation by rat bone marrow stromal cells. Calcif. Tissue Int. 64:69-77.

80. Hanada, K., Dennis, J.E., and Caplan, A.I. 1997. Stimulatory effects of basic fibroblast growth factor and bone morphogenetic protein-2 on osteogenic differentiation of rat bone marrow-derived mesenchymal stem cells. J. Bone Miner. Res. 12:1606-1614.

81. Triffitt, J.T. 1996. Fibroblast growth factor and vascular endothelial fibroblast growth factor families. In Principles of bone biology. Bilezikian, J.P., Raisz, L.G., and Rodan, G.A., editors. Academic Press. San Diego, CA. 627-645.

82. Kajkenova, O., et al. 1997. Increased adipogenesis and myelopoiesis in the bone marrow of SAMP6, a murine model of defective osteoblastogenesis and low turnover osteopenia. J. Bone Miner. Res. 12:1772-1779.

83. Allouche, M. 1995. Basic fibroblast growth factor and hematopoeisis. Leukemia. 9:937-942. 